\title{
兄的性格と弟的性格*
}

$\begin{array}{ccccc}\text { —双生肾研究 その一 } & \\ \text { 東京大学教育学部 } & \text { 三 } & \text { 木 } & \text { 安 } & \text { 正 }^{* *} \\ \text { 同 } & \text { 木 } & \text { 村 } & \text { 幸 } & \text { 子 }\end{array}$

\section{一 研究の目的}

一畉性双生児の対偶間には，多くの点で高い類似性が 見られるのであるが，性格の面では，両者の間にしばし ば差異があるとされている。すでに, 諏訪・岡田両氏*** は1942年及び1943年の双生児合宿研究において，そのこ とを穓察・記述している。そてには一畉性双生児(以下 $E Z$ と略記する) 11 組と二畉性双生児 (以下 Z Z と略記 する) 8 組について, 観察された性格の一致点と不一致 点が性格をあらわす言葉で羅列的に示されているが，Z Zの対偶者間には殆んどとり出せるような傾向がないの に対し，EZの対偶者間には可なり方向性のある羑異が みられる。その E Z の対偶者間にみられる性格の不一致 点をすべてあつめて，兄の方にみられる特徽と弟の方に みられる特改とに分け，似たようなものを集めてみる と，以下のようになる。(カッュ内の数は何回か出てき た場合の回数)

\section{兄}

自制的（4) 控元目 (3) 慎重, 遠虑がち, 多少気 重，決断がおそい，落着がある，はにかみ（2）

責任感強し, 指導的 (2) 努力的 (2) 皘極的, 決 断的

社交的, 協調的, 気軽, 卒直, 思いやり, 明朗, 活墢 軽卒, 吞気, 多弁, 移り気 (2) 落着なし (3)、無

* Elder-Brother-Like and Younger-Brother-Like 東京大学教育学部附属中・高等学校では昭 和 23 年以 来, 教育研究のため特に双生児を入学せしめている が, この研究はその中の一つで, 昭和28年度交部省科 学研究費「双生見研究班」Кよる研究の一部である。 な打この研究に扣りる卵性の影断は双生胃研究班の班 員諸氏によつて多くの項目について精密に行われたる のくよる。

** by Miki, Yasumasa (University of Tokyo) Kimura, Yukiko (University of Tokyo) *** 訆訪望, 岡田敬蔵「性格学々双生児研究」医学の 進步 6 (昭和 24 年)

\section{頓着}

注意散漫, 意志薄弱, 逃避的, 拒絶的, 反抗的, 感傷 的

\section{弟}

従属的（3）投げやり，飽き易い（2）気が散りや すい, 落着きなし，﨡従的

粗雑 (2) 粗暴, 浅薄, 放冕, 軽化, 多弁

我㦈 (4) 甘つたれ, 無力, 緩慢

利已的 (2) 感謝心な乙, 不平多し, 不平楾動家, 負けずぎらい, 競争心強し, 強情, 傲慢不係, 非和解 的, 補償的傾向強し, 反抗的

不誠実，陰険，狡猜，ひねくれ（2）ひがみ，㛽妬， 邪推心強し, 猜疑的, 執拗に復仇しょうとする, 残酷 無情, 不機嬚

内省的; 自制的, 空元目 (2) 慎重, 宑志, 気重, 遠㢝深い，几帳面，神䅅質

積極的, 高圧的

以上の二群の特徵を比べてみると，兄群には，慎重， 自制的で指導的な面と，社会的でのんきな面と，意志薄 弱, 逃避的といつた面がみられ, 弟群には, 従属的で放 䢠な面と，我儘で利己的な面と，不平，ひねくれなど好 ましくない評語が多く，また一面内省的，控え目といつ た面が含まれている。

そこで, 果して以上のような性格的な差異がEZの対 偶者間にみられるとすれば，E Zは本来全く同一素質の ものとされているので, その差異は生育過程において環 境的に形成された差異と考えられるのであり，それは， 一つには, 家庭における取扱い方の羑異, すなわち, 双 生児でありながら一方を兄または姉とし，他方を弟また は妹として遇するわが国のしきたりによるのではないか ということ，むう一つには，二人が成長していく間に， 体力的な面で, 知的能力の面で, あるいは生活程験の多 少といつた面で,さらには偶発的な事故, 疾病などによ つて生じた両都間の力関係の不均衡, 力の落差といつた 
あのから，両都間の依存関係に生じた模様のあるるのが 性格形成に影製するのではないかと考えられるのであ る。そこで，われわれの研究は，この二つの方向にさぐ りを入れなければならないわけであるが,* その研究の ためには，同胞間にみられる兄弟的性格の差異を測るた めのむのさしとなるものを作成する必要がある。その目 的で試みつつあるるのが本研究であるが，むろんまだ満 足な尺度が出来たというのではなく，今後の研究にまつ ことが多いるのである。

\section{二 兄弟的性格童暴を求めるための 問の作成と资料集めについて}

兄弟的性格差異を求めるための質問項目を作成するに ついては，まず前記の諏訪・岡田両氏の報告にある E Z の対偶者間の性格の不一致点としてあげられたるのを検 討してみた。そこで考えられたととは次のようなことで あつた。まず兄の方の性格的特徵の柱となつているもの は，兄的自賞とでもいうべきもので，自制的，指導的， 責任感，努力等で構成されているが，それは兄的優越と いつたものに裏ずけられる。そして，兄的優越の方が強 くなれば無頓着, のんきというようなるのが現れ総領の 甚六的になる。前記の報告では兄的自賞というようなカ テゴリーに入れられるような評語がずつと多い。さら に，その兄的自賞が，強くなりすぎたり，周囲からのそ うした期待が大きすぎたりすると，兄的自覚は兄的重圧 感となり (遠慮がち、はにかみ，気重，決断がおそい 等) さらに，重圧が強すぎると兄的フラストレーション といつたものが生ずる。（注意散漫，逃避的，拒絶的， 反抗的)

てれに対して弟の方の性格的特徵の柱となつているも のは，弟的従属及びそれに伴う開放感とでもいうべきる ので，従属的，投げやり，放冕，多茾等いわば責任のな い気軽な行動があらわれる一方，控え目，自制的なとい つた従属性むみられる。それは兄的俱越に対して自己の 爸繁を認めるととに表付けられるとてろもあるが(甘つ たれ，無力，湲慢等) その劣慜についての意識は弟的な 劣等感となる傾向が多く、ひがみや反抗，自閉傾向とな つて現われる(利已的, 不平, 競争心強し，非和解的） それが强くなると，弟的フラストレーションとでもいう ようなるのが生じ，陰険，狡猾，㵀妬，邪推，復仇，曳 酷といつた評語が可なり多い。

以上は，あるいは,こじつけに過ぎないるのかもしれ

* 二つの研究の方向の5ち, 前者はわれわれの第二報 告で, 後者は別榜古烟君の研究で, その一端が示され
ないし、なくもがなの考察かるしれないが,ともかく、 そんなととをふみ台として，兄的優越，兄的自觉，兄的 重圧, 兄的フラストレーションという四つのカテゴリー とそれに対庶する弟的のるの，及び兄的とも弟的ともい えないような性格,つまりどちらかといえば気質的とで あいうべきものの合計九つのカテゴリーに，それぞれ五 つずつの質問項目を作つて第一次の試案を作成し，昭和 27 年度と 28 年度に入学した双生児について実施してみ た。その結果, こうした試みが無䭾ではないらしいとい う期待がもてたので，その実施結果によつて若干の取㧽 を行い，不都合の部分（主として交章の誤解され易いも の）を改訂して作つたのが第二次案で，その項目は次 の通りである。

1 どちらがせつかちですか

2 どちらが扣しやべりですか

3 自分の着るものやるちすのКついて, よけいK短 にするのはどちらですか

4 摍題があると気になつて楽しく避べないのはどち らですか

5 なとかする時に人の迷惑になるかどらかをよけい К考えるのはどちらですか

6 しかられてもあまり気にしないのはどちらですか

7 小使をるららと早く伎つてしまらのはどちらで すか

8 自分の用事を平気で相手におしつけたり，たのん だりするのはどちらですか

9 人のいらことをなかなかはんきにしないのはどち らК多いですか

10 約束の時間におくれても，ままり気にしないのは ビちらですか

11 なにか気にくわないことがあるとすぐ据こつたり だまりこんだりするのはどちらですか

12 上く考えないらちに，仕事を始めて失敗すること の多いのはどちらですか

13 一つのことをつづけてやるよりも，次々と変つた ことをやるのが好きなのはどちらですか．

14 むりにでる自分の考えをと据そらとするのはどち らですか

15 るつと遊んでいたい時でも，やめなければならな い時には，すぐやめるのはどちらですか

16 なとか気にいらないことがあると，すく乱暴する のはどちらが多いですか

17 人にまだてられると,すぐ調子にのりやすいのは どちらですか

13 あまりしやべらないで人の郈を閒いていることが 
多いのはどちらですか

19 欲しいるのでる手を出さないで,えんりよするの はどちらですか

20 時々ちよつとずるいととをしたり，ごまかしたり するのはどちらですか

21 少しでる困ることがあると人にたよろらとするの はどちらですか

22 外にでて遊んだり，さわいだりするのが好きなの はどちらですか

23 あれこれ迷つてなかなか決心のつかないととが多 いのはどちらですか

24 仕事をする時ていねいに失敗のないよろにやるの はどちらですか

25 先に立つて計画し，人をみちびいていくのはどち らがすぐれていますか

26 人が困つている時に，すすんで手伝つてあげるの はどちらですか

27 自分ででをることでも，人Кやってもらいたがる のはどちらですか

28 人が親切にしてくれたことを喜んでらけとるのは どちらですか

29 ちよつとしたことですすぐ気にするのはどちらで 广加

30 あまり知らない人でも，すぐ把友達になれるのは どちらですか

31 どちらが負けずぎらいですか

32 いつすをちんとしていないと気がすまないのはど ちらですか

33 悲しいことを, 聞いたりみたりすると，すぐ涙を てばすのはどちらですか

34 人の前にでたりするのをきららのはどちらです 加

35 人に親切にしてあげるのは，どちらの方が多いで す加

36 どちらが托こりつぼいですか

37 めんどらなことはなるへくしないよらとするのは どちらですか

38 面白いことをいったり，したりして人を笑わせる のはどちらですか

39 人のいらことに反対することが多いのはどちらで すか

40 はきはきして、ほがらかなのはどちらですか

41 たのまれた仕事など，どちらの方がよくしますか

42 落着がなくて，いろいるのことに気がちるのはど ちらですか
43 電車の中站どで年寄や小さい子ねどに唐をゆザっ てあげるのはどちらですか

44 しなりればならないと思つた仕事を最後までやり と打すのはどちらですか

45 ほね扎しをしないで仕事を一生けんめいするの はどちらですか

調查は本年 2 月から 3 月の閒に, 次のような群を对象 にして行つた。

（1）昭和29年度東大附属中学に入学志願した双生児，

E Z. 男子 31 組，女子 24 組， Z Z. 男子 7 組, 女子 6 組。

これらに対して，双生児相互の評定，親の評定及び小 学校の担任の先生で両者を知つているものの評定, 計 4 通りの資料を得た。

(2) 普通の兄弟については，次に記す四つの中学校に ついて，それぞれ 1，2 年生各 4 組 (但し長野と秋田 は合せて 8 組分ぐらいに当る。に，まず，ひとりつ子 と同性の兄弟のないものを除いて, 最も年令の近い兄 弟と自分との性格の差異を評定させ，そのうちから年 令のひらきが 3 才以内のものを资料としてとつた。そ れによつて得られた资料の数は次の通りである。

(1) 豊島区高田中学校 (山手住宅地) 1,2 年生, 男子 76 名, 女子 62 名 [調查総数 336]

（） 江東区深川第四中学校 (下时工場地帯) 1,2 年生, 男子 105 名，女子 96 名 [調查総数 384]

(-) 長野県飯山中学校 (農村地带の町) 1,2 年生 男子 70 名, 女子 71 名 [調查総数 243]

$(\Rightarrow)$ 秋田県小野中学校 (農村地帯の町) 1,2 年生 男子 23 名, 女子 27 名 [調查総数 123]

そして，てれを長男(女)が次男(女)と比べたもの，長 男(女) ではない年長の兄(姉) が次の弟(妹) と比べたも の, 次男(女) 核長男(女) と比べたもの, 三男(女) 以下 の弟(妹)が，そのすぐ上の兄(姉)と比べたものの四つの グループにして整理した。

実施に当つて，最も注意をしたことは，ての場合の性 格評定は普通の意味で，その人の性格的特徴をたずねる のではなく，兄弟の間の差異を比較して，でくわずかで もより多くそういう傾向をむつている方に○をつける のだということの理解を徹底させることであつた。その ために次に揭げるような教示をプリントして，それによ つて検查者に十分に説明してもらうようにした。なお㛟 查者は, 東京の場合恃木村と東大教育心理学科の大学院 及び学部学生数名, 地方の場合はそれぞれの学校の教官 に化頼した。

教示「これから皆さんにいるいろの質問について答を 
書いてすらいます。それは，いろいろな性幊について， あなたとあなたの兄弟を比べてみて，そのちがいを答え てあらうあのです。……(略)

次質問が 45 ありますが，その一つ一つについて， 自分と相手との性質を比べるのです。「まず，どちらが せつかちですか」というのが一番目にありますが，そう きかれると自分む相手むせつかちではないと思う場合す あると思いますが，普通の人に比べれば両方ともとうで なくても，三人同志を比べれば、どつちかが少しよけい
せつかちだと思うことがあるでしよう。そして自分の方 が少しせつかちだと思つたら，自分の方をせつかちとし て下さい。……(以下略)」

\section{三結果の整理}

得られた結果の数値は第一表及び第二表に示す通りで あるが、てれを次のような手続きで整理した。なおZ Z は数が少ないので整理から省いた。

\section{1 鼠反店の引い項目}

Trable 1

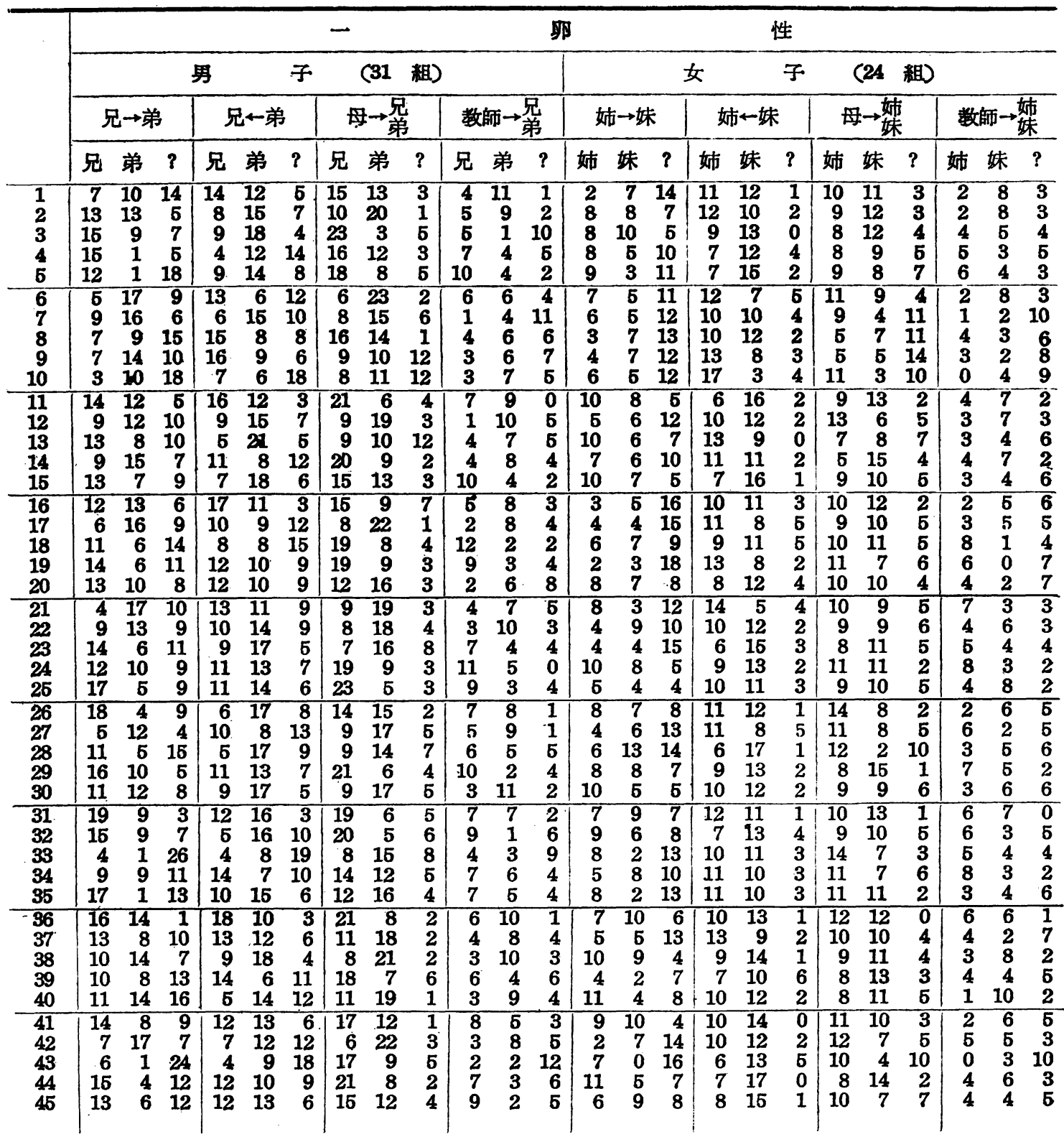


回答数の内で疑反応が半数あれば，その項目は一つの 傾向を示すものとしては不適当であるので，疑反応が半 数あるという仮説を立て、それを $5 \%$ の危险率で裹却で きないものをQとした。

\section{2 兄弟的性格羙異の琶められる項目}

つぎに疑反応を省き, 兄, 弟の欄に記入されている得 点だけを問題とし，その応答数について，兄の方がそう であるという反応が弟の方がそうであるという反応より む有意 (危险率 $5 \%$ 以下) に多くあらわれている項目を
E，その反対の頓向があらかれている項目をYとし，有 意の差がみとめられない項目をUとした。

\section{3 踶反底が多いわののうちの兄弟的性格盖置の みとめられる項目}

疑反庶が多いという前提のもとで，しかもとれが兄的 傾向を示す項目か, 弟的傾问を示す項目かということを みるために，さきにQとしたるのについて，その疑反応 を除いた応答数について, 前項 (2) の場合と同様に, 兄の方がそうであるという反応が弟の方がそうであると

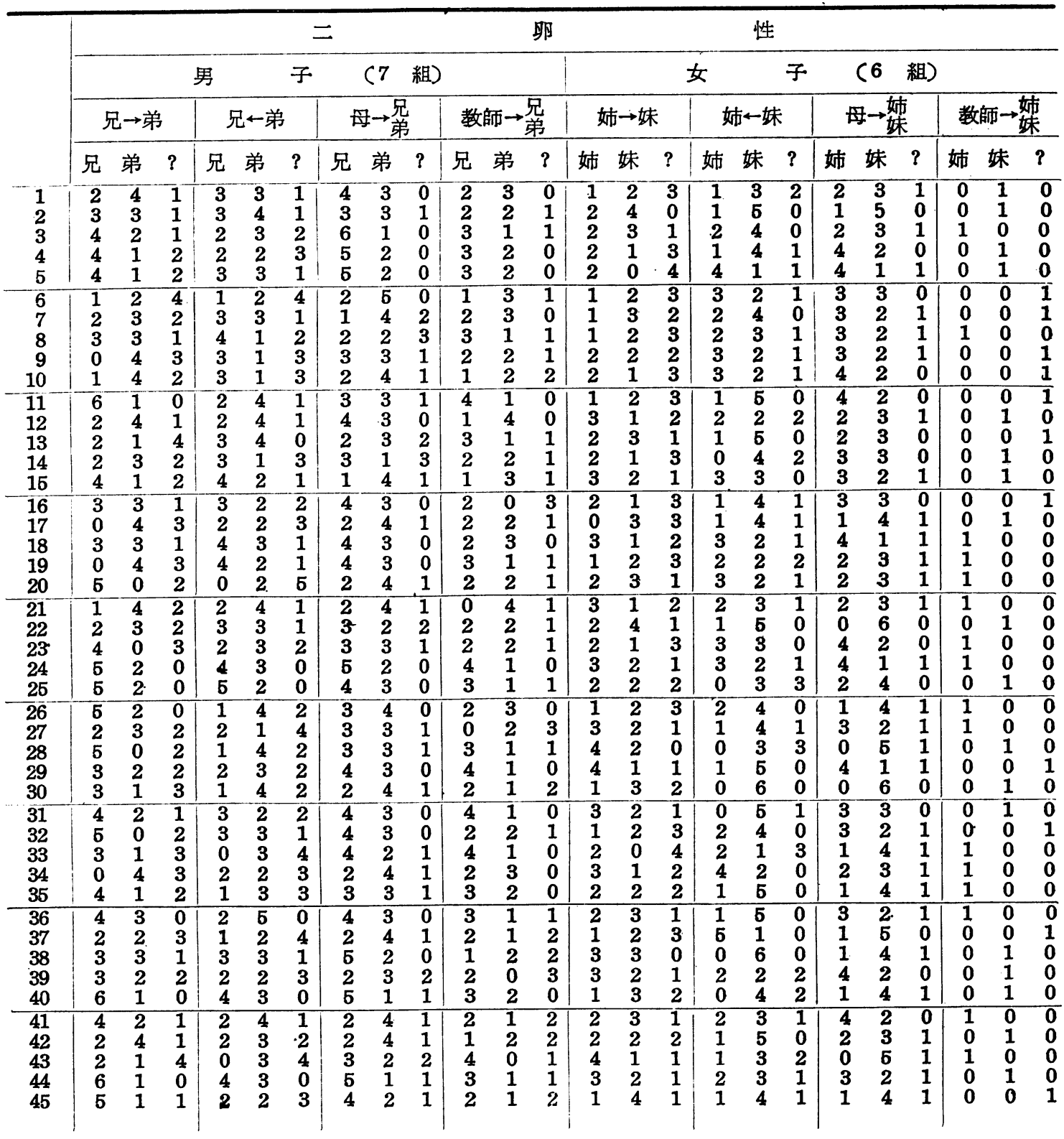


Table 2

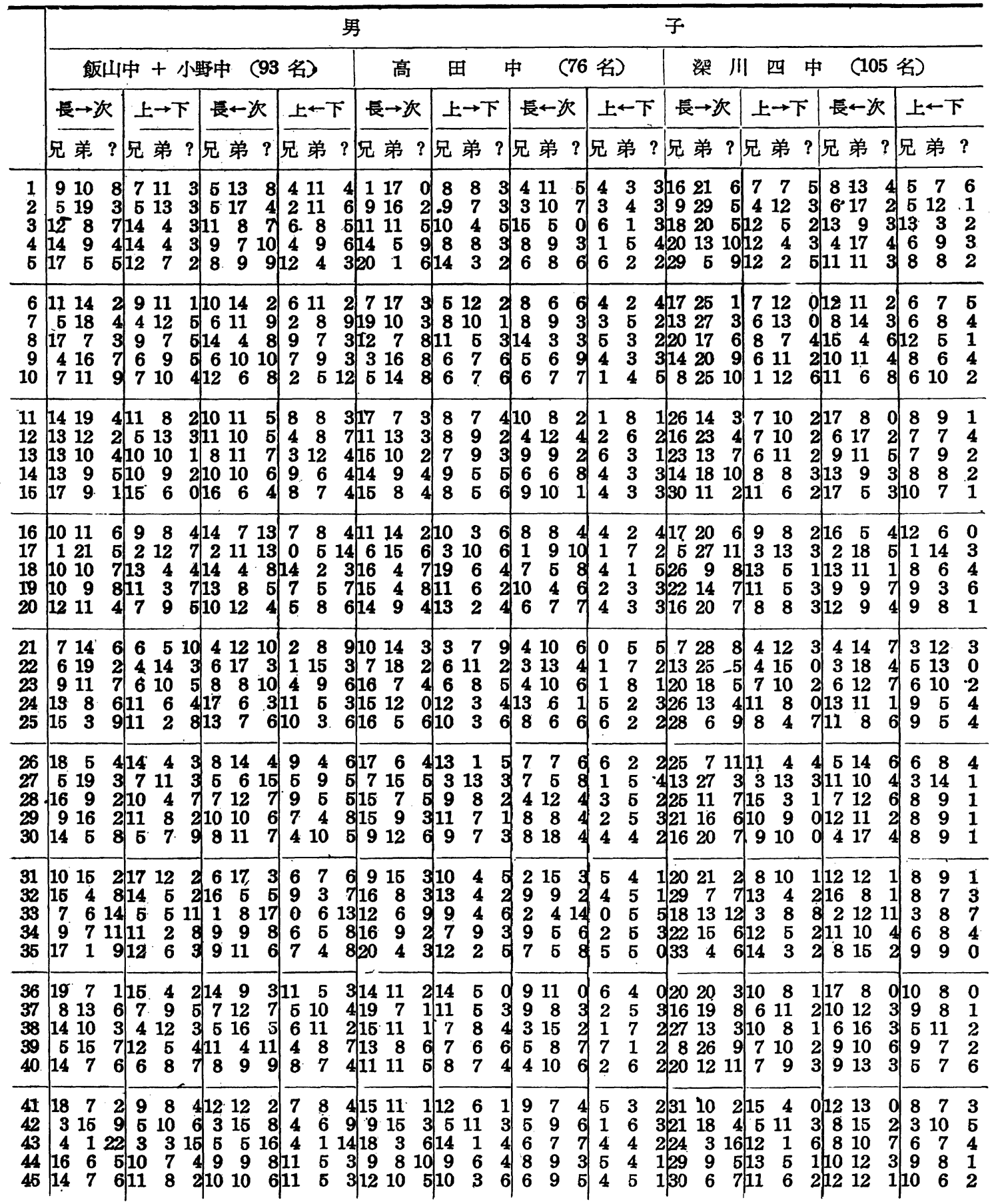

いう反结よりも有意 (危険率 $5 \%$ 以下) に多くあらわれ ている項目 Qe，その反对の傾向のあらわれている項目 を $\mathrm{Qy}$ さらに，有意の差のみとめられないものを $\mathbf{Q u}$ と した。
以上の整理の後, 双生児の場合については兄 $\rightarrow$ 弟, 弟 $\rightarrow$ 兄, 母 $\rightarrow$ 兄弟, 教師 $\rightarrow$ 兄弟の四者を通し，また普通の 兄弟の場合については, 長男 $\rightarrow$ 次思, 次男 $\rightarrow$ 長男, 年長 $\rightarrow$ 年少, 年少 $\rightarrow$ 年煨の四者を通じてみて, 


\begin{tabular}{|c|c|c|c|c|c|c|c|c|c|c|c|}
\hline \multicolumn{8}{|c|}{ 女 } & \multicolumn{4}{|l|}{ 子 } \\
\hline \multicolumn{4}{|c|}{ 飯山中＋小野中 (98 名) } & \multirow{2}{*}{$\frac{\text { 高 }}{\text { 長 } \rightarrow \text { 次 }}$} & \multirow{2}{*}{ 田 } & \multicolumn{2}{|c|}{ 中 (62 名) } & \multicolumn{2}{|c|}{ 深 川四中 } & \multicolumn{2}{|c|}{ (96 名) } \\
\hline 長 $\rightarrow$ 次 & 上 $\rightarrow$ 下 & 長匹次 & 上ヶ下 & & & 長—次 & 上ヶ下 & 長 $\rightarrow$ 次 & 上 $\rightarrow$ 下 & 長ヶ次 & 上ヶ下 \\
\hline
\end{tabular}

姉妹? 姉妹? 姉妹? 姉妹? 姉姝? 姉妹? 姉妹? 姉妹? 姉妹 ? 姉妹? 姉姝? 姉妹?

\begin{tabular}{l|lll|lll|lll|lll|lll|lllllll|llllllllllllll}
1 & 7 & 21 & 5 & 11 & 13 & 4 & 2 & 15 & 3 & 4 & 11 & 2 & 7 & 12 & 7 & 7 & 4 & 3 & 0 & 8 & 4 & 4 & 4 & 210 & 15 & 7 & 13 & 10 & 1 & 5 & 11 & 8 & 7 & 9 & 0
\end{tabular}

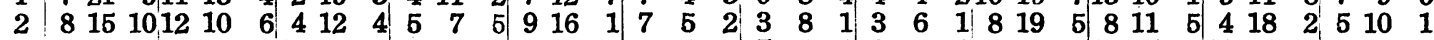
\begin{tabular}{llllllllllllll|llllllllllllllllllll}
3 & 16 & 15 & 818 & 3 & 712 & 6 & 2 & 6 & 10 & 113 & 8 & 5 & 8 & 4 & 2 & 7 & 4 & 1 & 3 & 6 & 118 & 12 & 216 & 7 & 111 & 8 & 5 & 8 & 6 & 2
\end{tabular}

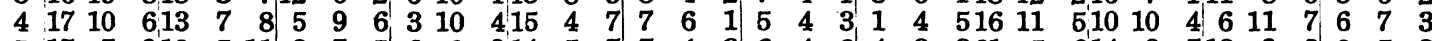
\begin{tabular}{llllll|lll|llllll|lllllllllllllllllllll}
5 & 17 & 7 & 912 & 5 & 11 & $\bullet 8$ & 7 & 5 & 6 & 2 & 9 & 14 & 5 & 7 & 7 & 4 & 3 & 6 & 4 & 2 & 4 & 3 & 321 & 5 & 6 & 14 & 3 & 7 & 13 & 9 & 2 & 8 & 5 & 3
\end{tabular}

$\begin{array}{lllllllllllllllllllllllllllllllllllll}6 & 7 & 19 & 7 & 7 & 18 & 3 & 9 & 7 & 4 & 7 & 8 & 2 & 7 & 14 & 5 & 4 & 8 & 2 & 5 & 6 & 1 & 3 & 4 & 311 & 18 & 3 & 7 & 15 & 2 & 11 & 8 & 512 & 3 & 1\end{array}$

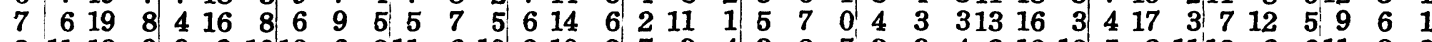

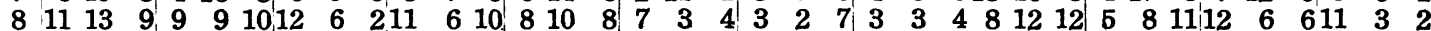
\begin{tabular}{llllll|lllll|lllllll|lllllllllllllllll}
9 & 10 & 15 & 813 & 8 & 7 & 9 & 6 & 5 & 10 & 3 & 14 & 5 & 7 & 14 & 4 & 6 & 4 & 3 & 4 & 5 & 3 & 3 & 411 & 11 & 10 & 12 & 6 & 6 & 10 & 7 & 7 & 6 & 7 & 3
\end{tabular}

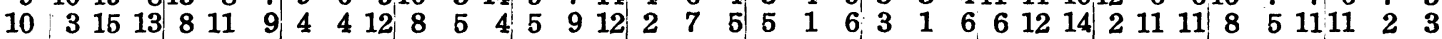

$\begin{array}{lllllllllllllllllllllllllllllllllllllllllllll}11 & 17 & 12 & 4 & 15 & 9 & 4 & 6 & 9 & 5 & 6 & 9 & 217 & 6 & 3 & 7 & 6 & 1 & 7 & 5 & 0 & 5 & 4 & 125 & 6 & 1 & 15 & 5 & 4 & 9 & 11 & 4 & 1 & 13 & 2\end{array}$ \begin{tabular}{l|lll|lll|lll|lll|lllllll|lll|llllllllllllll}
12 & 8 & 19 & 6 & 5 & 17 & 6 & 2 & 8 & 10 & 8 & 8 & 1 & 8 & 10 & 8 & 7 & 5 & 2 & 0 & 10 & 2 & 3 & 6 & 111 & 11 & 10 & 10 & 9 & 5 & 7 & 15 & 2 & 5 & 8 & 3
\end{tabular}

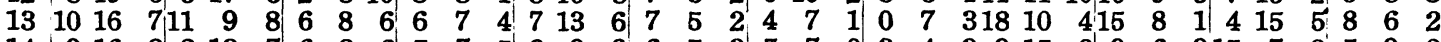
\begin{tabular}{l|llllll|llllll|llllllllllllllllllllllll}
14 & 9 & 16 & 8 & 8 & 13 & 7 & 6 & 8 & 6 & 5 & 7 & 5 & 8 & 9 & 9 & 6 & 5 & 3 & 5 & 7 & 0 & 3 & 4 & 3 & 9 & 15 & 8 & 9 & 6 & 9 & 15 & 7 & 2 & 5 & 9 & 2
\end{tabular} $\begin{array}{llllllllllllllllllllllllllllll}15 & 22 & 2 & 922 & 2 & 4 & 11 & 6 & 311 & 5 & 117 & 5 & 410 & 4 & 0 & 7 & 2 & 3 & 6 & 2 & 219 & 7 & 617 & 5 & 212 & 7 & 5 & 8 & 6 & 2\end{array}$

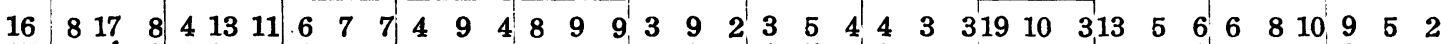
\begin{tabular}{l|lllllllll|llllll|lll|lll|llllll|llllllllll}
17 & 4 & 20 & 9 & 4 & 16 & 8 & 1 & 5 & 14 & 6 & 4 & 7 & 5 & 18 & 3 & 3 & 9 & 2 & 1 & 7 & 4 & 3 & 4 & 1 & 4 & 23 & 5 & 2 & 13 & 9 & 3 & 7 & 14 & 3 & 10 & 3
\end{tabular} \begin{tabular}{llll|lll|lll|lll|llllll|lllllllllllllllll}
18 & 15 & 11 & 7 & 9 & 10 & 9 & 7 & 8 & 5 & 7 & 9 & 112 & 7 & 7 & 6 & 7 & 1 & 7 & 2 & 3 & 5 & 4 & 115 & 7 & 10 & 9 & 8 & 7 & 10 & 10 & 4 & 6 & 7 & 3
\end{tabular}

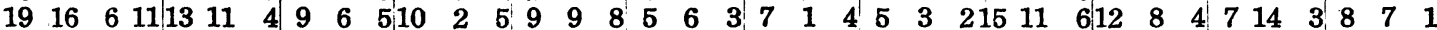
\begin{tabular}{lllllllllll|lll|llllllllllllllllllllllll}
20 & 8 & 13 & 12 & 9 & 9 & 10 & 5 & 10 & 5 & 6 & 8 & 3 & 8 & 9 & 9 & 6 & 5 & 3 & 2 & 7 & 3 & 2 & 5 & 314 & 7 & 11 & 10 & 13 & 11 & 8 & 6 & 10 & 7 & 6 & 3
\end{tabular}

\begin{tabular}{l|lll|lll|lll|lll|lll|lllllllllllll|lll|lll|lll|}
21 & 6 & 22 & 5 & 7 & 10 & 11 & 4 & 11 & 5 & 2 & 11 & 4 & 3 & 16 & 7 & 4 & 7 & 3 & 1 & 5 & 6 & 3 & 7 & 0 & 7 & 18 & 7 & 9 & 10 & 5 & 5 & 12 & 7 & 2 & 12 & 2
\end{tabular} $\begin{array}{llllllllllllllllllllllllllllllllllllll}22 & 3 & 26 & 4 & 3 & 23 & 2 & 2 & 12 & 6 & 1 & 15 & 1 & 4 & 17 & 5 & 4 & 10 & 0 & 3 & 7 & 0 & 2 & 5 & 311 & 9 & 2 & 3 & 16 & 5 & 3 & 15 & 6 & 2 & 14 & 0\end{array}$ \begin{tabular}{llllllllllllll|lllllllllllllllllll}
23 & 12 & 16 & 513 & 8 & 7 & 4 & 8 & 8 & 7 & 4 & 613 & 8 & 5 & 9 & 2 & 3 & 3 & 9 & 0 & 3 & 5 & 2220 & 9 & 314 & 4 & 6 & 6 & 15 & 3 & 6 & 8 & 2
\end{tabular} \begin{tabular}{llllll|llllllllllllll|lllllllllllll}
24 & 16 & 20 & 714 & 9 & 5 & 11 & 5 & 4 & 9 & 6 & 213 & 9 & 4 & 7 & 6 & 1 & 9 & 2 & 1 & 7 & 2 & 1 & 13 & 9 & 1014 & 9 & 112 & 12 & 0 & 8 & 7 & 1
\end{tabular}

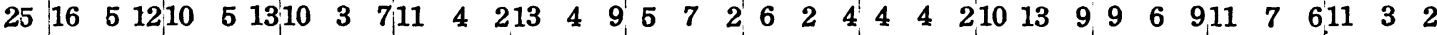

$\begin{array}{lllllllllllllllllllllllllllllllllll}26 & 22 & 5 & 620 & 7 & 1 & 7 & 7 & 6 & 7 & 7 & 311 & 5 & 1010 & 3 & 1 & 3 & 5 & 4 & 2 & 5 & 317 & 9 & 617 & 4 & 3 & 4 & 16 & 4 & 3 & 12 & 1\end{array}$

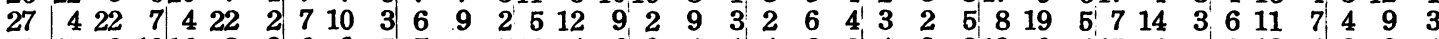
$\begin{array}{lllllllllllllllllllllllllllllllllllll}28 & 15 & 8 & 1016 & 3 & 9 & 6 & 9 & 5 & 7 & 5 & 516 & 4 & 6 & 9 & 4 & 1 & 4 & 6 & 2 & 4 & 3 & 319 & 9 & 415 & 4 & 5 & 8 & 12 & 4 & 3 & 9 & 4\end{array}$ \begin{tabular}{lllllllllllllll|lllllllllllllllllll}
29 & 22 & 7 & 4 & 16 & 8 & 4 & 7 & 10 & 3 & 5 & 9 & 317 & 4 & 5 & 9 & 3 & 2 & 2 & 6 & 4 & 5 & 5 & 018 & 11 & 318 & 3 & 3 & 7 & 16 & 1 & 6 & 10 & 0
\end{tabular}

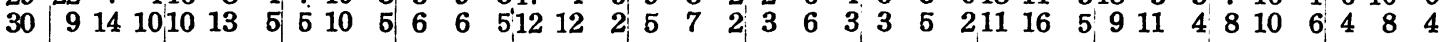

$\begin{array}{llllllllllllllllllllllllllllllllllllllllllllllllll}31 & 10 & 16 & 7 & 14 & 11 & 3 & 7 & 12 & 1 & 7 & 8 & 212 & 9 & 5 & 6 & 6 & 2 & 2 & 5 & 5 & 3 & 7 & 017 & 11 & 4 & 10 & 10 & 4 & 7 & 16 & 1 & 5 & 9 & 2\end{array}$ \begin{tabular}{lllllllll|llllllll|llllllllllllllll}
32 & 22 & 6 & 521 & 3 & 4 & 11 & 8 & 1 & 6 & 9 & 219 & 2 & 5 & 12 & 1 & 1 & 4 & 7 & 1 & 4 & 3 & 320 & 10 & 218 & 2 & 4 & 12 & 7 & 5 & 7 & 9 & 0
\end{tabular}

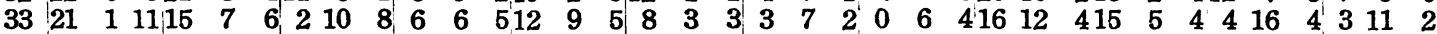

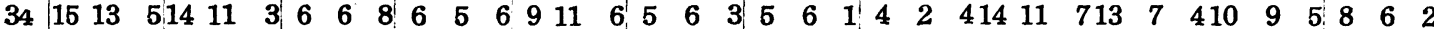
\begin{tabular}{lllllllllllllll|lll|llllllllllllllll}
35 & 17 & 4 & 1219 & 4 & 5 & 6 & 7 & 7 & 6 & 5 & 615 & 4 & 7 & 8 & 1 & 5 & 2 & 5 & 5 & 4 & 4 & 217 & 11 & 4 & 13 & 6 & 5 & 7 & 12 & 5 & 4 & 11 & 1
\end{tabular}

$\begin{array}{lllllllllllllllllllllllllllllllllll}36 & 16 & 11 & 617 & 8 & 312 & 7 & 110 & 6 & 115 & 8 & 3 & 5 & 9 & 0 & 5 & 4 & 3 & 6 & 3 & 1 & 19 & 11 & 213 & 10 & 1 & 9 & 14 & 1 & 6 & 8 & 2\end{array}$ $\begin{array}{llllllllllllllllllllllllllllllllllll}37 & 9 & 16 & 812 & 11 & 5 & 6 & 8 & 6 & 9 & 6 & 2 & 7 & 11 & 8 & 9 & 2 & 3 & 2 & 8 & 2 & 4 & 5 & 116 & 12 & 4 & 13 & 5 & 6 & 9 & 12 & 3 & 6 & 8 & 2\end{array}$

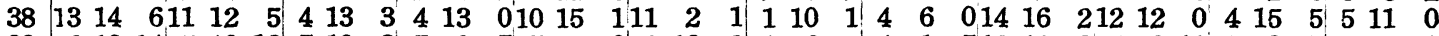
\begin{tabular}{l|lll|llllllllllllllllllllllllllllllllll}
39 & 6 & 13 & 14 & 5 & 10 & 13 & 7 & 10 & 3 & 7 & 3 & 7 & 7 & 6 & 13 & 2 & 10 & 2 & 1 & 6 & 5 & 4 & 1 & 5 & 12 & 12 & 8 & 5 & 8 & 11 & 8 & 9 & 7 & 8 & 5 & 3
\end{tabular}

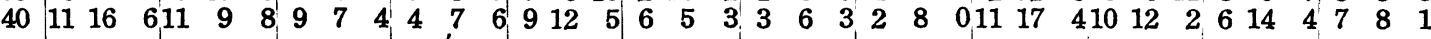

\begin{tabular}{llllllllllll|lllllllll|llllllllllllllll}
41 & 20 & 8 & 522 & 5 & 1 & 8 & 9 & 3 & 5 & 11 & 1 & 17 & 6 & 3 & 6 & 6 & 2 & 6 & 5 & 1 & 3 & 5 & 220 & 10 & 215 & 5 & 4 & 8 & 16 & 0 & 4 & 10 & 2
\end{tabular}

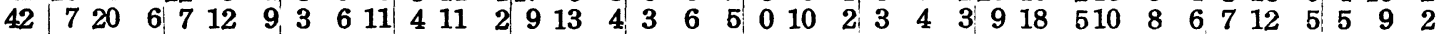
$\begin{array}{lllllllllllllllllllllllllllllllllllll}43 & 18 & 1 & 14 & 13 & 1 & 14 & 6 & 3 & 11 & 5 & 1 & 11 & 16 & 4 & 6 & 9 & 2 & 3 & 3 & 4 & 5 & 4 & 3 & 316 & 3 & 1315 & 0 & 9 & 10 & 6 & 8 & 7 & 3 & 6\end{array}$

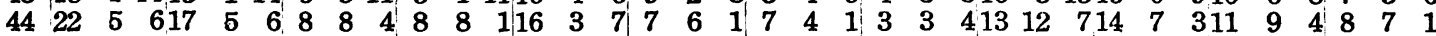

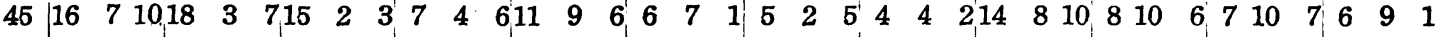

1. 四者とも同じ傾向をもち，そのうちにEを三つ以 上含むものをの，Yを三つ以上含むものを䧄

2. 四者とも同じ傾向をもち，そのうちにEを二つも つ本のを(A)，Yを二つもつものを(B)
3、 EをたはYを二つ以上もつが，Uを一つ含むもの をAまたはB

4. 四者を通じてすべて同じ傾向で，EまたはYを一

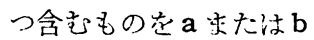


とした。

以上の基淮によって, E Z の男女別, 三地域の中学生 の男女別について，45項目中傾向のはつきりあらわれた ものを，その順に従つて第15位まで序列をつけ，上記の 基準の記号と合せ記したものが第三表である。

ただし，aまたはb市での基準に当るすのが１6に到 らないものが相当ある。

\section{四結果の考察}

まず，第三表についてみよう。これは前記のように， かなり大きくく〉つたものなのであるから，大まかな考 察になるが,
（1）兄弟的性格差異は双生児より普通の兄弟間によ り多く見られる。むろん，その中のある部分は兄弟的性 格差異というより，個人的性格差異というべきものも含 まれていようが。

(2) 兄弟的性格差異は女子よりも男子にずっと強く みられる。

(3) (1) (2) のととに関連して, 第三表をみると，a または b までの基準にあう項目が，EZ男子，飯山・小 野中男子、深川四中男子では第16位まで満たされており， 高田中男子のみが第 13 位まで。゙゙あるが女子では飯山・ 小野中女子が第 14 位まで，深川四中女子が第 10 位ま で，高田中女子が第 9 位まで，E Z 女子は第2 位までに

Table 3

\begin{tabular}{|c|c|c|c|c|c|c|c|c|c|}
\hline & $\begin{array}{c}\text { E Z } \\
\text { 男 }\end{array}$ & $\begin{array}{c}\text { E Z } \\
\text { 女 }\end{array}$ & 飯山 $_{\text {男 }}^{\text {小野 }}$ & 高田中 & 深川四中 & 女 & $\begin{array}{c}\text { 高田中 } \\
\text { 女 }\end{array}$ & 深川四中 & 壾 \\
\hline $\begin{array}{l}1 \\
2 \\
3 \\
4 \\
5\end{array}$ & A 13 & $\begin{array}{ll}\text { b } & 2\end{array}$ & $\begin{array}{ll}\text { (i) } & 2 \\
\text { A } 11 \\
\end{array}$ & $\begin{array}{lr}\text { a } & 13 \\
\text { A } & 6 \\
\end{array}$ & $\begin{array}{l}\text { (6) } \\
\text { a } 10 \\
\end{array}$ & 14 & & (B) 4 & $\begin{array}{l}\mathrm{b} \\
\mathrm{a} \\
\mathrm{a} \\
\text { (A, } \mathrm{A} \times 3, \mathrm{a} \times 2\end{array}$ \\
\hline $\begin{array}{r}6 \\
7 \\
8 \\
9 \\
10\end{array}$ & B 11 & & $\begin{array}{ll}5 & 5 \\
8 & 8\end{array}$ & & $\begin{array}{ll}\text { a } & 12 \\
\text { a } & 16\end{array}$ & (B) 6 & & B & $\begin{array}{l}\text { B, } \\
\text { (9), a } \\
\text { B }\end{array}$ \\
\hline $\begin{array}{l}11 \\
12 \\
13 \\
14 \\
15\end{array}$ & (18) 4 & & A 12 & b $\quad 11$ & (A) & $\begin{array}{ll}\text { B } & 8 \\
\text { (4) } 3\end{array}$ & $\begin{array}{ll}\text { a } & 9 \\
& \\
\text { a } & 7\end{array}$ & $\begin{array}{ll}\text { A } & 8 \\
\text { (A) } 5\end{array}$ & $\begin{array}{l}\mathrm{A}, \mathrm{a} \\
\text { (B), } \mathrm{B}, \mathrm{b} \\
\text { (A) } \times 3, \mathrm{~A}, \mathrm{a}\end{array}$ \\
\hline $\begin{array}{l}16 \\
17 \\
18 \\
19 \\
20\end{array}$ & $\begin{array}{lr}\mathrm{B} & 6 \\
\mathrm{~A} & 7 \\
\mathrm{a} & 14\end{array}$ & & () 4 & $\begin{array}{l}\text { a } \\
\text { A } \\
\text { 4 }\end{array}$ & $\begin{array}{ll}\text { (9) } & 1 \\
\text { (A) } & 8\end{array}$ & $\begin{array}{rr}\text { B } & 9 \\
\text { a } & 13\end{array}$ & (B) 1 & (3) 2 & $\begin{array}{l}\text { (1) } 3, \text { (B), B } \times 2 \\
\text { (1), A, a } \\
\mathrm{a} \times 2 \text {, }\end{array}$ \\
\hline $\begin{array}{l}21 \\
22 \\
23 \\
24 \\
25 \\
\end{array}$ & 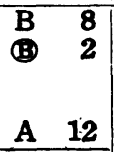 & $\begin{array}{ll} & 1\end{array}$ & $\begin{array}{lr}\text { B } & 15 \\
\text { (8) } & 1 \\
& \\
\text { (8) } & 6 \\
\end{array}$ & $\begin{array}{rr}b & 10 \\
\text { (9) } & 1 \\
& \\
\text { a } & 9 \\
\text { (4) } & 2\end{array}$ & \begin{tabular}{|rr} 
(e) & 3 \\
ie) & 2 \\
a & 13 \\
a & 14 \\
\end{tabular} & $\begin{array}{ll}\text { (i) } & 4 \\
\text { (i) } & 2\end{array}$ & $\begin{array}{ll}\text { b } & 5 \\
\text { b } & 6 \\
\text { a } & 8\end{array}$ & (B) & $\begin{array}{l}\text { (B) } \times 2, \mathrm{~B} \times 2, \mathrm{~b} \times 2, \mathrm{a} \\
\mathrm{B} \times 4, \mathrm{~B} \times 2, \mathrm{~b} \\
\mathrm{a} \times 3 \\
\text { (A, (A, } \mathrm{A}, \mathrm{a}\end{array}$ \\
\hline $\begin{array}{l}26 \\
27 \\
28 \\
29 \\
30\end{array}$ & $\begin{array}{ll}\stackrel{\text { (i) }}{\mathbf{A}} & 1 \\
\end{array}$ & & A 14 & A 3 & (2) 6 & a 12 & & b 10 & $\begin{array}{l}\mathrm{A} \times 2, \mathrm{a} \\
\text { (B) } \\
\mathrm{A}\end{array}$ \\
\hline $\begin{array}{l}31 \\
32 \\
38 \\
34 \\
35\end{array}$ & A 10 & & (4) 3 & A & $\begin{array}{ll}\text { (A) } 7 \\
\text { a } & 11\end{array}$ & $\begin{array}{l}\text { A } 10 \\
\text { A } 11\end{array}$ & $\begin{array}{ll}\text { A } & 3 \\
\text { a } & 4\end{array}$ & & $\begin{array}{l}\mathrm{A}, \mathrm{A}, \mathrm{A} \times 2 \\
\mathrm{~A} \times 2, \mathrm{a} \times 2\end{array}$ \\
\hline $\begin{array}{l}36 \\
37 \\
38 \\
39 \\
40\end{array}$ & 15 & & $\begin{array}{lr}\text { (A) } & 7 \\
\text { B } & 13\end{array}$ & $\begin{array}{ll}\text { A } & 7 \\
\text { B } & 8\end{array}$ & & (B) 7 & & & $\begin{array}{l}\text { (A) } \\
\text { (B) } \\
\text { b }\end{array}$ \\
\hline $\begin{array}{l}41 \\
42 \\
43 \\
44 \\
45\end{array}$ & $\begin{array}{ll}\text { (B) } & 3 \\
\text { (A) } & 5\end{array}$ & & $\begin{array}{r}\text { (B) } \\
\text { A } \\
10\end{array}$ & & A & (A) 5 & $\mathbf{A}$ & (A) & $\begin{array}{l}\text { (B) } \times 2 \\
\text { (A) }, \mathrm{A} \\
(\text { (A) } \times 2, \quad \mathrm{~A} \times 2\end{array}$ \\
\hline
\end{tabular}


過ぎない。

（4）兄的性格より弟的性格の方がはつきりと出てき ている。第三表でも後の第四の表でる, 兄弟的性格差異 のけん暒に出てくる上位 3 番目までは，いずれも弟の方 である。

（5）地域的には，兄弟的性格差異は，男女を通じ， 飯山・小野中 (農村), 梁川四中 (大都市下町), 高田中 (大都市山手) の順に強くあらわれている。

これが家族的封建性と関係があるのかどうかという問 題は第二報告で考察する。

（6）普通の兄弟の場合について, 六つの生徒群 (3 学校・男女)を通じで,一定の傾向を示しているるのを, その傾向の強さと，その傾向の各群に現われる頻度とを にらみ合せて 10 項目えらんでみると（結局 11 項目に なつたが) 次のものがあげられる。

Table 4

\begin{tabular}{|c|c|c|c|c|}
\hline 序 & $\begin{array}{l}\text { 項目 } \\
\text { 番号 }\end{array}$ & 差異傾向の強さ & $\begin{array}{l}\text { 傾向の } \\
\text { 現われ } \\
\text { た群数 }\end{array}$ & 項目の特徵 \\
\hline 1 & 22 & (B) $\times 4$, (B), $b$ & 6 & 快活, 社交的 \\
\hline 2 & 17 & (ㄷ) $\times 3$, (B), $\mathrm{B}$ & 5 & 調子もの \\
\hline 3 & 21 & (B), (B) $\times 2, \mathrm{~B}, \mathrm{~b} \times 2$ & 6 & 依存的 \\
\hline 4 & 5 & (A, $A \times 2, \quad a \times 2$ & 5 & 控え目 \\
\hline 5 & 32 & (A), (A), $\mathrm{A} \times 2$ & 4 & 几帳面 \\
\hline 6 & 15 & (A) $\times 3, A, a$ & 5 & 自制的 \\
\hline 7 & 2 & (B) $\times 2$, (B) & 3 & 多弁 \\
\hline 8 & 35 & $A \times 2, a \times 2$ & 4 & 親切 \\
\hline S & 25 & (A), (A), $\mathbf{a}$ & 3 & 指導的 \\
\hline 10 & 44 & (A), $\mathrm{A} \times 2$ & 3 & 責任感 \\
\hline 11 & 38 & (B), $\mathrm{B} \times 2$ & 3 & こつけい \\
\hline
\end{tabular}

すなわち，この結果によつて，

兄的性格とされたのは，自制的，控え目，几帳面, 親 切, 指導的, 責任感が強い,

弟的性格とされたのは, 快活, 社交的, 調子にのりや すい, 依存的,多弁,こつけいというような傾向である。

（7）上記の普通の兄弟にみられた性格的差異を双生 児のそれ (男子の場合) と比べてみると大体において一 致した傾向がみられ，ことに上位のものは全く一致して いる。普通の兄弟に現われていて双生児にあらわれてな い項目は 32，15，2，35，38 などであるが，双生児に 現われていて普通の兄弟に出ていないのは，

6 (しかられてもあまり気にしない)……………弟

12 (よく考えないうちに仕事をはじめて失敗す

$$
\text { ることが多い)……………………………..弟 }
$$

18 (あまりしやべらないで人の話をきいている
のが多い)………………………….......兄

19 (ほしいものでも手を出さないで遠慮する)…兄

28 (人が親切にしてくれたことを喜しでうけと る) 弟

29 (ちよつとしたことですすぐ気にする)………兄

31 (負けずぎらい)………………………………兄

40 (はきはきしてほがらかう..............................弟

42 （落着きがなくて、いろいろのことに気がち る)

などであつて，普通の兄弟にみられた性格差異の傾向と 相反するものではない。項目の再検討をして整理すれば 当然一致するであろう。

（8）EZ女子には兄弟的性格差異がほとえど明らか にはあらわれていない。

（9）45項目中，兄弟的性格差異をほとんど示さない 項目は次のものである。(仮りに第三表中一つも記号の ない項目だけをとつた。)

4 宿題があると気になつて楽しく遊べないのはどち らですか

9 人のいうことをなかなかほてきにしないのはどち らに多いですか

13 一つのことをつづけてやるよりも，次々と変つた ことをやるのが好きなのはどちらですか

14 むりにでも自分の考えをとおそうとするのはどち らですか

16 なにか気にいらないことがあると、すぐ乱暴する のはどちらですか

23 あれこれ迷つてなかなか決心のつかないことが多 いのはどちらですか

30 あまり知らない人とでもすぐお友達になれるのは どちらですか

33 悲しいことを, 聞いたり見たりするとすぐ淚を こぼすのはどちらですか

34 人の前にでたりするのをきらうのはどちらですか

39 人のいうことに反対することが多いのはごちらで すか

41 たのまれた仕事など,どちらの方がよくしますか これらの項目をみると，判断の材料になるような場面 やことがらが手近にないような質問であること，自分の 気もちの方は判るとしても，それに対応する相手の気も ちは推察しかねるような質問であること，中学の $1 \cdot 2$ 年生ぐらいのものには少しむうかかいかもしれない質間 であること、などが反省される。

(10) 上記 (9) の項目について，抢互いに相手の方が そうだとし合ったり，逆にお互いに自分の方がそういう 
傾向があるのだと考えたりする項目はどれかというのを みると

普通の兄弟の方で三つの学校の男女という六つの群の うち五つの群で同じような傾向をしめしたのは質問 4， 宿題があると気になつて楽しく遊べないのはどちらか， で互に自分の方だとしている。

6 群中 4 群が同じ傾向をしめしているのは 質問33 悲 しいことを聞いたり，みたりするとすぐ淚をこぼすの はどちらですか,でやはり互に自分の方としている。

これに対して双生児では，こうした関係がもつと微細 に出てくるのではないかと思われるので, 差の検定をし てみると，1\%の危険率で有意の差があるものは，男子 では

4 宿題があると気になつて楽しく遊べないのは自分

6 しかられてる余り気にしないのは 自分

13 一つことをつうけてやるよりも次々と变つた ととをやるのが好きなのは 自分

23 あれこれ迷つてなかなか決定のつかないこと が多いのは

31 どちらが負けずぎらいですか

自分

自分
などで,女子にはない。

次に $5 \%$ の危険率にさげれば有意の差があるのは，男 子では

3 自分の着るものや持ちものについて余計気に するのは

自分

9 人のいうことをなかなか本気にしないのは，自分

33 悲しいことをみたり，きいたりすると，すぐ涙を こぼすのは

自分

女子では 13 (自分)と 16 何か気にいらないことがあ るとすぐ乱暴するのはどちらが多いか 自分 のニつである。いく分でも悪い方のことは相手方におし やるというような傾向はあまりない。

以上の結果に見られたようにまだこの兄弟的性格差 異をつかむための質問項目は検討, 改訂を要するもので あるが, 改善の可能性はあると思われるので, 今後改訂 をして行きたいと思う。結果の検討に当つては，われわ れの研究室の東洋君にいろいろお手伝いをいただいた。 ここに謝意を表する。 


\title{
ABSTRACTS
}

\section{ELDER-BROTHER-LIKE AND YOUNGER-BROTHER-LIKE}

\author{
By Miki, Yasumasa and Kimura, Yukiko \\ Tokyo University
}

\section{Problem.}

Despite their similarities, it is known that there are some personality differences between members of a pair of identical twins.

According to the observations of Suwa and Okada, it seems that some of these differences may be reduced to the differences between elderbrother-like characteristics and younger-brotherlike characteristics. These differences may be dependent on (1) the japanese family system in which elder son and younger son are differently treated by parents and other members of the family and (2) the superior-inferior relationship or interdepending relationships due to differences in physical and mental capacities between two members who are essentially identical and are always compared by others.

As the first approach to these problems, the authors tried to make up a convenient questionnaire to evaluate elder-brother-like personality and younger-brother-llke personality.

Subjects and procedures

Based on Suwa and Okada's observations on fraternal personality differences, a questionnaire consisting of 45 items was composed. Each item described on behavior characteristic. The subjects was expected to answer whether this characteristic was more dominant in him or in his brother. If it was difficult to decide, the subject was allowed to check "not known."

This questionnaire was answered by 31 pairs of mal identical twins, 24 pairs of female identical twins, and 274 boys (76 from residentical quarters, 105 from commercial and industrial quarters of Tokyo and 93 from rural area) and 256 girls
(62, 96,98 respectively). The non-twin all had siblings of the same sex and the age difference being less than 3 years. All subjects were 12-14 years old.

Results

Paw scores are shown in Table 2. These are summed up in Table 3 for each item according to whether differences between responses "elder" and "younger" are statistically significant or not. In this table the sign means that the item got significantly larger number of "elder responses in the group, while (s) means that the "younger" responses were prevailing. The signs (A) and (B) means that though the differences were significant, the item also had "not known" responses larger than the critical number. The sign A, B, $a$, and $b$ indicate that there were some tendencies but not significant.

Following results are found from Table 3.

1. Fraternal personality differences between nontwin sib ings were greater than those between identical twins.

2. Fraternal personality differences were greater in brothers than in sisters.

3. Younger-brother-like characteristics are more definite than the elder-brother-like characteristics.

4. Fraternal personality differences are more marked in rural children than in the city children, and more in commercial quarters than in residential quarters.

5. Fraternal personality differences were detected by following items.

1: item 22 Likes to play outdoors......younger 2. " 17 More easily influenced by others 
......younger.

3. " 21 Is dependent in difficult situations ......younger.

4. " 5 More concerned whether his actions will bother people.......elder

5. " 32 Is concerned unless every thing is in order......elder.

6. 15 Stops playing immediately when necessary even though he would like to continue playing......elder
7. " 2 Talkative......younger
8. " 35 Is kind......elder
9. " 25 Is a leader......elder
10. " 44 Carry throngh on his places......elder
11. " 38 Entertains others by telling jokes and funy stories......younger

6. Fraternal personality differences between twins had similare tendencies.

7. Personality characteristics of elder brother type were manifested by self-control, moderative, neatness, kindness, leadership, and sense of responsibility, personality characteristics of younger brother type were manifested by gaiety, sociability, easily influenced, dependency, talkativeness, and humorous.

By improving these items of the questionnaire, it is feld that personality characteristics of the elder brother type and the younger brother type can be further studied. In the following report the relationship between fraternal personality differences and the handling of the children in the home will be discussed.

\title{
ON PERSONALITY DIFFERENCE AND INTERDEPENDENT RELATIONSHIP IN IDENTICAL TWINS
}

\author{
By Furuhata, Kazutaka \\ Tokyo University
}

\section{Purpose :}

To grasp pereonality differences in identical twins who have been growing up in the so-called "eame environment" (with no organic defect) in connection with their interdependent relationship.

Subjects :

18 pairs of twins, aged about 12 years, all were pupils of the Middle School attached to TokyoUniversity. They consisted of 12 pairs of identical twins, 4 pairs of fraternal twins of the same sex and 2 pairs of fraternal twins of unlike-sex.

Procedure :

1) The behavioral characteristics and the differences between the twins ( $A$ and $B$ ) of each pair and the behavioral characteristics of the whole were outlined by observing their behavior at school for about half a year and during summer camp for a week.

2) Various personality tests were given. The children were asked to rate both themselves and their twins. The ratings given by each pair of twins were compare 1 to determine the degree of agreement in their responses.

3) Three series of problem-solving experiments were conducted with both twins, participating conditions were changed and frustrating situations were presented so that the author could observe the response patterns, attitudes toward the goals and interdependent relationships.

Results and Conclusions :

1) Though the high degree of personality resemblance of identical twins has been emphasized, from the bio-social point of view, considerable differences in fundamental behavioral characteri- 